\title{
PENGARUH LINGKUNGAN KERJA DAN DISIPLIN KERJA TERHADAP KINERJA KARYAWAN PT. INFOMEDIA NUSANTARA BAGIAN CALL CENTER TELE ACCOUNT MANAGEMENT (TAM) TELKOM BANDUNG
}

\author{
Dewi Puspita Sari ${ }^{1}$, Imelda Megawati ${ }^{2}$, Imam Heriyanto ${ }^{3}$ \\ Sekolah Tinggi Ilmu Ekonomi Pasundan 1,2,3 \\ Email: dewipuspita777@gmail.com ${ }^{1}$,imelda@stiepas.ac.id ${ }^{2}$,imam@stiepas.ac.id ${ }^{3}$
}

\begin{abstract}
This research aims to find and analyze the impact of the work environment and work discipline on employee performance. This study uses descriptive analysis and verification analysis with 75 respondents. Besides, this study uses path analysis. The result shows that the work environment is adequate, the result of the work discipline is acceptable, and employee performance is decent. The direct and indirect effect of the work environment on performance is 0,458. The direct and indirect effect of work discipline on performance is 0,303. The entire effect is 0,761. Coefficient determination is 76,1\%, and the rest is $24,0 \%$ from the other variables that affect employee performance, but they are not analyzed in this study.
\end{abstract}

Keywords: work environment, work discipline, employee performance.

\begin{abstract}
Abstrak
Tujuan penelitian ini untuk mengetahui dan menganalisis pengaruh lingkungan kerja dan disiplin kerja terhadap kinerja karyawan. Penelitian ini menggunakan metode analisis deskriptif dan analisis verifikatif dengan data sampel yang dikumpulkan dalam penelitian ini sebanyak 75 responden. dengan hasil penelitian ini menggunakan analisis jalur. Hasil penelitian menunjukkan bahwa lingkungan kerja memperoleh hasil cukup baik, disiplin kerja memperoleh hasil cukup baik, dan kinerja karyawan memperoleh hasil cukup baik. Sedangkan pengaruh langsung dan tidak langsung lingkungan kerja terhadap kinerja sebesar 0,458 dan pengaruh langsung dan tidak langsung disiplin kerja sebesar 0,303. Sehingga total pengaruhnya yaitu 0,761 . Koefisien determiasi $76,1 \%$ dan sisanya sebesar $24,0 \%$ yaitu variabel lain yang mempengaruhi kinerja karyawan akan tetapi tidak diteliti.
\end{abstract}

Kata kunci: lingkungan kerja, disiplin kerja, kinerja. 
April, 2020

\section{PENDAHULUAN}

Saat ini dunia telah memasuki era globalisasi atau dikenal juga sebagai era modernisasi. Modernisasi telah menyentuh segala aspek kehidupan manusia mencakup bidang ilmu pengetahuan dan juga teknologi dimana mayoritas manusia pada era ini sudah sangat bergantung pada teknologi sehingga menjadikannya kebutuhan dasar setiap orang dari mulai anak muda, orang tua, para ahli, bahkan masyarakat awampun pada saat ini sudah terbiasa dalam penggunaan teknologi, terutama teknologi pada bidang informasi dan komunikasi. Hal ini pula lah yang mendasari perkembangan industri informasi dan telekomunikasi yang semakin pesat secara global, termasuk juga di Indonesia. Menurut data yang diperoleh dari informasi lembaga Produk Domestik Bruto (PDB), bahwa sektor informasi dan telekomunikasi memberikan kontribusi sebesar 5\% terhadap PDB nasional pada tahun 2017, dan mengalami pertumbuhan hingga $9,81 \%$ pada awal tahun 2018. Sehingga dari sini kita bisa melihat bahwa memang industri ini berkembang begitu pesatnya, sehingga dengan tingkat perkembangan yang begitu pesat ini, turut berimbas pada persaingan bisnis pada industri telekomunikasi yang semakin ketat.

Segala aspek Sumber Daya yang dimiliki oleh perusahaan baik berupa uang, bahan baku, metode, peralatan mesin dan pangsa pasar tidak bisa memberikan hasil yang optimum apabila tidak didukung oleh adanya sumber daya manusia yang efektif, sehingga Sumber Daya Manusia memiliki peran yang sangat strategis dalam upaya pencapaian tujuan dan sasaran sebuah perusahaan. Untuk itu maka perusahaan harus memiliki Sumber Daya Manusia yang handal dan berkualitas yang dapat diukur melalui penilaian kinerja karyawan yang diberlakukan oleh perusahaan yang bersangkutan.

PT Infomedia Nusantara merupakan anak perusahaan pada Telkom Group yang mengkhususkan diri di bidang media penerbitan dan iklan sebagai jembatan komunikasi antar pelaku bisnis dan juga saluran informasi bagi pelanggan telepon Telkom. Oleh karenanya, PT Infomedia Nusantara juga termasuk salah satu perusahaan yang bergerak pada bidang teknologi informasi dan telekomunikasi dengan tingkat persaingan yang sangat ketat sehingga perusahaan harus memikirkan strategi untuk mengupayakan organisasinya tetap bisa bertahan dan memenangkan persaingan. Pada tahap berikutnya, PT Infomedia Nusantara juga mengembangkan bisnisnya sebagai sebuah perusahaan yang bergerak dalam bidang layanan Call Center Tele Account Management (TAM) yang menyediakan jasa outsourching secara mandiri untuk aktivitas pemasaran maupun peningkatan kualitas layanan dan hubungan antara mitra Infomedia Nusantara dengan pelanggannya. Layanan konten yang diberikan perusahaan terfokus pada penyediaan data sesuai dengan kebutuhan mitra dan pelanggan. Hal ini dipicu terutama oleh adanya perubahan lingkungan bisnis pada industri terkait dan juga

Bisnis Dan Iptek | Sekolah Tinggi Ilmu Ekonomi Pasundan Bandung 
April, 2020

banyaknya kompetitor yang memberikan jasa layanan yang serupa, sehingga tentu saja PT Infomedia Nusantara harus mengupayakan agar mereka bisa selalu lebih unggul dan tidak tertinggal. Maka, sebagai perusahaan yang bergerak pada bidang jasa, disamping produk yang ditawarkan haruslah memiliki kualitas yang unggul, PT Infomedia Nusantara juga harus tetap bisa menjaga konsistensi kualitas kinerja dari para karyawannya, termasuk juga kinerja dari para karyawan bagian Call Center Tele Account Management (TAM) yang dimilikinya, mengingat dalam tugasnya, bagian ini melakukan kontak secara langsung dengan pelanggan melalui media telepon selular, tentu kinerja terbaik yang mereka kontribusikan akan sangat berpengaruh dalam menentukan keberhasilan dan memiliki peran sentral untuk meningkatkan penjualan setiap produk yang dimiliki perusahaan.

Pada aspek kualitas terdiri dari indikator Customer Service Orientation, Team Work dan Product Knowledge sedangkan pada aspek kuantitas terdiri dari indikator Achievement Orientation, Organization Commitment, Performance dan Initiative. Kemudian, berdasarkan laporan penilaian kinerja Karyawan Bulan Januari - Desember 2018 diperoleh informasi bahwa kinerja karyawan PT Infomedia Nusantara bagian Call Center Tele Account Management (TAM) Telkom dari bulan Januari hingga Desember 2018 target yang ditentukan pada aspek kualitas dan kuantitas tidak tereleasasi atau mencapai target $100 \%$. Pada aspek kualitas yang paling rendah pada bulan Oktober yaitu 83\%. Kemudian pada aspek kuantitas yang terendah pada bulan Desember yang hanya mencapai $68 \%$. Pada realisasinya rata-rata pencapaian aspek kualitas dari bulan Januari sampai dengan Desember 2018 yaitu 88,75\% dan pada aspek kuantitas mencapai 79,33\%. Sehingga dari data ini dapat disimpulkan bahwa kinerja karyawan PT Infomedia Nusantara bagian Call Center Tele Account Management (TAM) Telkom belumlah optimal, yang mana hal ini diduga dipengaruhi oleh faktor Lingkungan Kerja yang belum optimal.

Bommer, Johnson, Rich, Podsakoff \& MacKenzie (1995) menyatakan bahwa kinerja karyawan dipengaruhi beberapa factor seperti gaji, lingkungan kerja, budaya organisasi, kepemimpinan dan motivasi kerja, disiplin kerja, kepuasan kerja, dan motivasi. Berdasarkan pendapat tersebut, dapat kita ketahui bahwa faktor yang mempengaruhi kinerja ada berbagai macam, salah satunya adalah lingkungan kerja yang merupakan faktor penting dalam menciptakan kinerja karyawan. Lingkungan kerja memiliki peran penting dalam meningkatkan kinerja karyawan melalui lingkungan kerja fisik dan non fisik yang baik, hal demikian dapat menciptakan suasana yang aman dan nyaman bagi para karyawan dalam suatu organisasi, diantaranya dengan memberikan fasilitas-fasilitas dan alat bantu keselamatan bekerja, menjaga kebersihan tempat bekerja, membuat keterbukaan antara sesama karyawan maupun pimpinan, meningkatkan moral karyawan dalam

Bisnis Dan Iptek | Sekolah Tinggi Ilmu Ekonomi Pasundan Bandung 
setiap aktivitas, sehingga jika kondisi fisik dan non fisik sudah memadai maka produktivitas kerja akan mengalami peningkatan.

Berdasarkan data yang peneliti dapatkan mengenai Lingkungan Kerja PT Infomedia Nusantara bagian Call Center Tele Account Management (TAM) Telkom Bandung, terlihat masih terdapat banyak karyawan belum mampu untuk mencapai standar pelayanan yang sudah ditentukan. Hal tersebut juga dipicu terutama dikarenakan kurangnya fasilitas penunjang kerja karyawan sehingga menyebabkan kurang optimalnya kinerja karyawan dalam bekerja, maka untuk memastikan fenomena tersebut dilakukan penyebaran kuisioner kepada 30 orang karyawan, dan berdasarkan hasil pra-survey tersebut, diketahui bahwa lingkungan kerja mendapatkan nilai rata-rata sebesar 2,8 dengan kriteria Cukup Baik. Hal tersebut diatas dapat dilihat dari dua dimensi, diantaranya lingkungan fisik dengan skor sebesar 3,15 dengan kategori Cukup Baik artinya karyawan merasa bahwa lingkungan fisik yang ada diperusahaan belum cukup optimal untuk menunjang kegiatan mereka dalam melakukan tugas-tugasnya. kemudian lingkungan non fisik memperoleh skor 2,5 dengan kategori Kurang Baik dimana diketahui karyawan tidak secara optimal memperoleh bimbingan dan motivasi dari atasan terkait pekerjaan.

Selain lingkungan kerja, faktor lain yang diduga mempengaruhi kinerja yang belum optimal yaitu disiplin kerja Call Center Tele Account Management (TAM) Telkom belum optimal. Seperti kita ketahui bahwa karyawan yang disiplin juga akan bekerja secara efektif dan efisien sehingga terhindar dari pemborosan waktu dan energi dan hal ini tentu akan meningkatkan kinerja karyawan sehingga mampu memberikan kontribusi positif untuk keberhasilan perusahaan, kemudian Bugdol (2018) mengemukakan bahwa dengan adanya tingkat disiplin kerja yang baik mencerminkan kredibilitas karyawan mencapai suatu hasil kerja yang optimal untuk kesuksesan perusahaan.

Berdasarkan hasil pra-survey yang dilakukan, terlihat bahwa disiplin kerja PT Infomedia Nusantara bagian Call Center Tele Account Management (TAM) Telkom Bandung belum optimal karena seharusnya masih dapat ditingkatkan. Disiplin Kerja memperoleh skor rata-rata 2,9 dengan kategori cukup baik. Hal ini bisa dilihat dari dimensi kehadiran yang memperoleh skor rata-rata sebesar 2,85 dengan kategori cukup baik. Dimensi ketaatan pada peraturan kerja memperoleh skor rata-rata 2,9 dengan kategori cukup baik, Kemudian dari dimensi ketaatan pada standar kerja memperoleh skor rata-rata 3,0 dengan kategori cukup baik, dimensi tingkat kewaspadaan tinggi memperoleh skor rata-rata 2,75 dengan kategori cukup baik, dan pada dimensi bekerja etis memperoleh skor rata-rata 3,4 dengan kategori cukup baik. 
Wood (2018) menunjukkan bahwa disiplin kerja sangat diperlukan untuk menunjang kelancaran segala aktivitas organisasi agar tujuan organisasi dapat dicapai secara maksimal. Disiplin kerja dapat dilihat sebagai sesuatu yang besar manfaatnya, baik bagi kepentingan organisasi maupun kepentingan karyawan. Bagi organisasi adanya disiplin kerja akan menjamin terpeliharanya tata tertib dan kelancaran pelaksanaan tugas, sehingga diperoleh hasil yang optimal. Adapun bagi karyawan akan diperoleh suasana kerja yang menyenangkan sehingga akan menambah semangat kerja dalam melaksanakan pekerjaannya.

Dari serangkaian pemaparan diatas, bisa kita pahami bahwa lingkungan kerja mempunyai pengaruh langsung terhadap karyawan di dalam menyelesaikan pekerjaan yang pada akhirnya akan meningkatkan kinerja organisasi. Suatu kondisi lingkungan kerja dikatakan baik apabila karyawan dapat melaksanakan kegiatan secara optimal, sehat, aman dan nyaman, suasana kerja yang baik seperti ruang kerja yang kondusif diharapkan akan mendukung kinerja seorang pegawai. Kemudian, Faktor lain yang dapat mempengaruhi kinerja yaitu faktor disiplin kerja. Salah satu potensi karyawan yang penting dalam mendorong kinerja adalah kedisiplinan. Manajemen perusahaan yang baik biasanya selalu memiliki tingkat kedisiplinan yang tinggi. Kedisiplinan dapat dilihat dari bagaimana karyawan mengerjakan tanggung jawabnya sesuai dengan aturan yang telah ditetapkan. Hal ini sesuai dengan pendapat Latainer bahwa disiplin merupakan kekuatan yang ada di dalam diri karyawan yang menyebabkan karyawan secara sukarela mematuhi peraturan dan keputusan yang ada di perusahaan. (Sutrisno: 2011). Maka berdasarkan uraian tersebut di atas juga didukung oleh pendapat para ahli, maka rumusan masalah ini adalah bagaimana pengaruh lingkungan kerja dan disiplin kerja terhadap kinerja karyawan secara parsial maupun simultan. Maksud dan tujuan penelitian ini untuk mengetahui besarnya pengaruh lingkungan kerja dan disiplin kerja terhadap kinerja karyawan secara parsial maupun simultan.

\section{KERANGKA PEMIKIRAN}

Meningkatkan kualitas sumber daya manusia akan termanifestasikan dalam kinerja SDM dalam melaksanakan tugas dan peran yang di embannya sesuai dengan tuntutan organisasi. oleh karena itu upaya mengelola dan mengembangkan kinerja individu dalam organisasi menjadi hal yang sangat penting dalam membangun dan mengembangkan kemampuan organisasi untuk dapat berkembang secara optimal. Kinerja merupakan hasil kerja secara kualitas dan kuantitas yang dicapai oleh seorang pegawai dalam melaksanakan tugasnya sesuai dengan tanggung jawab yang diberikan kepadanya. Kinerja dalam menjalankan fungsinya tidak berdiri sendiri, tetapi berhubungan dengan lingkungan kerja serta disiplin kerja karyawan. Menurut Chandraseka (2011) Lingkungan kerja berhubungan dengan disiplin kerja yang dapat mendorong sikap disiplin pegawai,

Bisnis Dan Iptek | Sekolah Tinggi Ilmu Ekonomi Pasundan Bandung 
karena lingkungan merupakan serangkaian sifat kondisi kerja yang dapat diukur berdasarkan presepsi bersama dari para anggota perusahaan/instansi yang hidup dan bekerjasama dalam suatu perusahaan/instansi tersebut, kemudian Wood (2018) bentuk disiplin yang baik akan tercermin pada suasana dilingkungan kerja. Chandraseka (2011) hubungan lingkungan kerja dengan disiplin kerja sangatlah tinggi, karena perasaan senang yang ditunjukkan oleh pegawai dan kecocokan pegawai dengan peraturan perusahaan/instansi mencerminkan lingkungan kerja yang nyaman, hal tersebut juga dapat meningkatkan kinerja pegawai. Dari pendapat di atas, dapat dilihat jelas bahwa ada pengaruh disiplin dalam lingkungan kerja. Bahwa karyawan yang merasa cocok dengan peraturan yang berlaku di perusahaan/instansi cenderung bekerja secara maksimal dan perasaan senang yang ditimbulkannya dapat berpengaruh terhadap lingkungan sekitarnya.

Menurut Pindek \& Spector (2016) pengaruh lingkungan kerja adalah segala sesuatu hal atau unsur-unsur yang dapat mempengaruhi secara langsung maupun tidak langsung terhadap perusahaan yang akan memberikan dampak baik ataupun buruk terhadap kinerja pegawai, kemudian Dirks \& Ferrin (2000) menyebutkan bahwa kinerja pegawai dipengaruhi oleh ekstrinsik pegawai. Factor ekstrinsik yang mempengaruhi kinerja pegawai terdiri dari lingkungan fisik dan non fisik, kepemimpinan, komunikasi vertical dan horizontal, kompensasi, control berupa penyelesaian, fasilitas, pelatihan, beban kerja, prosedur kerja, system hukuman dan sebagainya.

Menurut Motowidlo \& Kell (2012) karyawan yang disiplin sejak berangkat, saat bekerja, dan saat pulang bekerja serta sesuai aturan dalam bekerja, akan memiliki kinerja yang baik. Faktor disiplin kerja juga berpengaruh terhadap kinerja seseorang dalam instansi/perusahaan. Hal ini sejalan dengan yang telah dijelaskan Soss, Fording \& Schram (2011) bahwa adanya pengaruh antara disiplin kerja dengan kinerja yang dicapai seseorang, artinya semakin baik disiplin kerja semakin baik pula kinerja yang dicapai seseorang. Semakin tinggi tingkat kedisiplinan kerja pegawai maka semakin tinggi pula kinerja pegawai yang dihasilkan. Menurut Mangkunegara (2011) disiplin pegawai merupalan pembenrukan kondisi uang optimal, sehat, aman dan nyaman. Kesesuaian lingkungan kerja dapat dilihat hasilnya dalam jangka waktu yang lama, jika lingkungan kerja yang kurang baik maka dapat menuntut tenaga kerja dan waktu yang lebih banyak pula. Sutrisno (2010) mengemukakan adanya dua factor yang mempengaruhi kinerja yaitu, factor lingkungan dan disiplin individu, faktor-faktor individu yang dimakud adalah; Usaha yang menunjukkan sejumlah sinergi fisik dan mental yang digunakan dalam menyelenggarakan gerakan tugas, Abilities, yaitu sifat-sifat personal yang diperlukan untuk melaksanakan suatu tugas.

Bisnis Dan Iptek | Sekolah Tinggi Ilmu Ekonomi Pasundan Bandung 
April, 2020

\section{METODE PENELITIAN}

Metode penelitian adalah serangkaian tata cara atau langkah yang sistematis atau terstruktur dan dilakukan oleh seorang peneliti untuk mengumpulkan data dengan tujuan menguji kebenaran dari hipotesis yang telah dirumuskan. Metode yang digunakan dalam penelitian ini adalah metode deskriptif dan verifikatif. Metode deskriptif berfungsi untuk mendeskriptifkan atau memberi gambaran terhadap objek yang diteliti melalui data sampel atau populasi yang sebagaimana adanya, tanpa melakukan analisis dan membuat kesimpulan yang berlaku untuk umum, kemudian penelitian verifikatif adalah suatu penelitian yang ditunjukkan untuk menguji teori dan penelitian akan mencoba menghasilkan informasi ilmiah baru yakni status hipotesa, yang berupa kesimpulan apakah suatu hipotesa diterima atau ditolak. Metode verifikatif ini untuk mencapai kolerasi atau pengaruh dari variable-variabel yang diteliti terhadap variable lain yaitu variable bebas dan variable terikat, selain itu juga dilakukan untuk menguji kebenaran sutau hipotesa melalui pengolahan data yang diperoleh dari responden yang dilakukan secara langsung.

Sedangkan pendekatan yang digunakan dalam penelitian ini adalah pendekatan kuantitatif, karena data lingkungan kerja dan disiplin kerja yang diperoleh berupa data kuantitatif. Data yang dibutuhkan adalah data yang sesuai dengan masalahmasalah yang ada dan sesuai dengan tujuan penelitian, sehingga data tersebut akan dikumpulkan, diolah, dianalisis, dan di proses lebih lanjut sesuai dengan teori-teori yang telah dipelajari dan kemudian akan dapat ditarik suatu kesimpulan. Tempat penelitian ini penulis mengadakan penelitian pada PT Infomedia Nusantara bagian Call Center Tele Account Management (TAM) Telkom Bandung Kegiatan penelitian dilakukan selama 6 bulan.

Operasional Variabel dalam penelitian ini yaitu:

1. Variabel Bebas (Independent Variable), Variabel bebas atau independent merupakan variabel yang mempengaruhi atau menjadi sebab timbulnya atau berubahnya variabel dependen (variabel terikat). Dalam penelitian ini yang merupakan variabel bebasnya adalah lingkungan kerja sebagai "X1" dengan dimensi lingkungan kerja fisik dan lingkungan kerja non fisik (Sedarmayanti, 2013) dan disiplin kerja sebagai "X2" dengan dimensi kehadiran, ketaatan pada aturan kerja, ketaatan pada standar kerja, tingkat kewaspadaan tinggi, dan bekerja etis (Rivai, 2011).

2. Variabel terikat atau dependen merupakan variabel yang dipengaruhi atau yang menjadi akibat karena adanya variabel bebas (independent). Dalam penelitian ini yang merupakan variabel terikat adalah kinerja sebagai "Y" dengan dimensi Kualitas dan Kuantitas (PT. Infomedia Nusantara).

Populasi merupakan keseluruhan subyek penelitian. Apabila seseorang ingin meneliti semua elemen yang ada dalam wilayah penelitian, maka penelitiannya 
merupakan penelitian populasi atau studi populasi atau studi sensus. Kemudian sampel adalah bagian dari jumlah dan karakteristik yang dimiliki oleh populasi tersebut. Populasi dalam penelitian ini adalah seluruh karyawan Call Center Tele Account Management (TAM) Telkom Bandung, dengan menggunakan rumus slovin dengan taraf signifikansi 5\% diperoleh jumlah sampel sebanyak 52 orang karyawan. Teknik analisis data menggunakan analisis jalur, hal tersebut dilakukan dengan pertimbangan untuk mengetahui pengaruh langsung maupun tidak langsung antar variabel penelitian sehingga dapat diperoleh hasil penelitian yang lebih komprehensif.

\section{HASIL DAN PEMBAHASAN}

Sebelum dianalisis terlebih dahulu dilakukan pengujian asumsi klasik. Hasil Uji Normalitas dapat dilihat bahwa grafik histogram memberikan pola distribusi yang melenceng ke kanan, selain itu sebagian besar bar/batang berada di bawah kurva yng berarti bahwa histogram dari nilai perusahaan berdistribusi normal. Berdasarkan gambar P-Plot terlihat titik-titik mengikuti dan mendekati garis diagonalnya, sehingga dapat disimpulkan bahwa data berdistribusi normal. Selain dengan uji histogram dan juga P-Plot, untuk lebih meyakinkan maka perlu dilakukan pengujian statistik melalui Uji One-Sample Kolmogorov-Smirnov Test (uji K-S). Dari hasil pengujian uji K-S, Asymp.Sig. (2-tailed)" nilai dari data unstandardized residual menunjukan angka 0,200 yang artinya lebih besar dari 0,05 menunjukan bahwa uji K-S telah terpenuhi yang artinya data berdistribusi normal.

Hasil pengolahan data menunjukkan semua variabel penelitian valid dan reliabel. Sedangkan hasil pengujian dengan menggunkan analisis jalur adalah sebagai berikut:

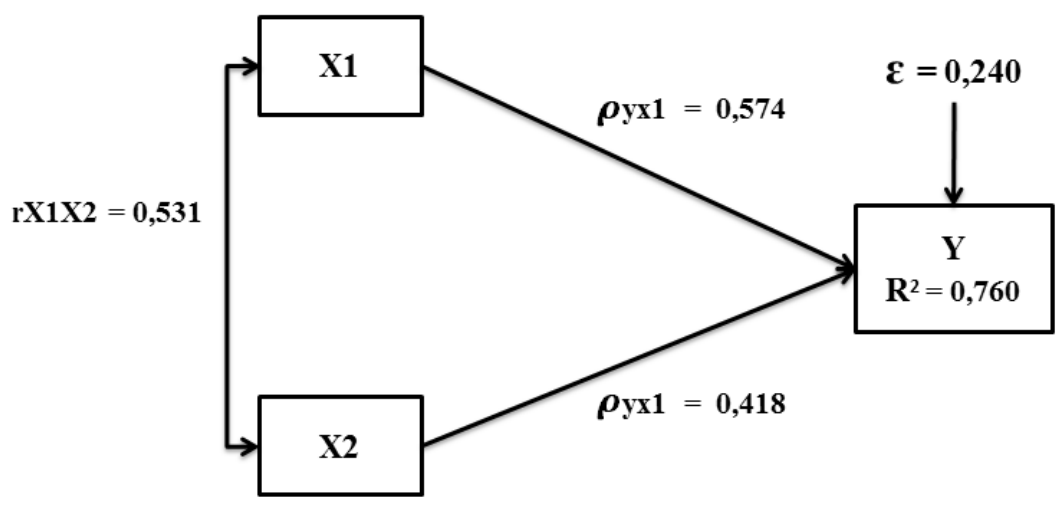

Gambar 1. Pengaruh Lingkungan Kerja dan Disiplin Kerja Terhadap Kinerja Karyawan 
Berdasarkan hasil perhitungan, menggambarkan hasil perhitungan jalur, bahwa variabel X1 mempunyai koefisien jalur sebesar 0,574, variabel X2 mempunyai koefisien jalur 0,418. Besarnya pengaruh masing-masing variabel bebas terhadap variabel terikat baik pengaruh langsung maupun Pengaruh Tidak Langsung. Hasil perhitungan bahwa pengaruh langsung variabel Lingkungan Keja (X1)terhadap variabel Kinerja (Y) yaitu sebesar 0,330 atau 33,0\% dan pengaruh tidak langsung variabel lingkungan Kerja (X1) tehadap Kinerja (Y) melalui variabel Disiplin Kerja (X2) yaitu sebesar 0,128 atau $12,8 \%$ sehingga total pengaruh variabel Lingkungan Kerja (X1) yaitu sebesar 0,458 atau 45,8\%. Sedangkan pengaruh langsung variabel Disiplin Kerja (X2) terhadap variabel Kinerja (Y) yaitu sebesar 0,175 atau 17,5\%, dan pengaruh tidak langsung variabel Disiplin Kerja (X2) terhadap Kinerja (Y) melalui variabel Lingkungan kerja (X1) yaitu sebesar 0,128 atau $12,8 \%$ sehingga total pengaruh variabel Disiplin Kerja (X2) yaitu sebesar 0,303 atau $30,3 \%$.

Variabel Lingkungan Kerja (X1) mempunyai total pengaruh sebesar 0,458 atau $45,8 \%$, sedangkan Disiplin Kerja(X2) mempunyai total pengaruh sebesar 0,303 atau 30,3\%. Maka variabel yang paling dominan atau berpengaruh terhadap Kinerja yaitu Lingkungan Kerja. Dari hasil perhitungan koefisien determinasi ( $R$ kuadrat) yang dinyatakan dalam presentase menggambarkan besarnya Total pengaruh semua variabel bebas yaitu Lingkungan Kerja (X1) dan Disiplin Kerja (X2) terhadapKinerja Karyawan (Y) yaitu sebesar 0,760 atau 76,0\% dan besaran epsilon atau faktor lain yang tidak diteliti dan turut berpengaruh terhadap kinerja karyawan yaitu $\rho \mathbf{y} \varepsilon=0,240$ atau $24,0 \%$, seperti motivasi, kompensasi, pelatihan kerja, budaya kerja, kepemimpinan, dan kepuasan kerja.

Variabel Lingkungan Kerja (X1) mempunyai dua dimensi yaitu lingkungan kerja fisik dan lingkungan kerja non fisik. Berdasarkan hasil pengolahan data yang dilakukan, maka diperoleh gambaran mengenai lingkungan kerja (X1) memiliki nilai rata-rata sebesar 2.92 berada pada kategori Cukup Baik. Hal ini menunjukkan bahwa responden memberikan penilaian yang cukup baik terhadap variabel Lingkungan Kerja pada PT Infomedia Nusantara bagian Call Center Tele Account Management (TAM) Telkom Bandung. Berikut pernyataan tertinggi yang pertama yaitu pada nomor 1 yang memiliki nilai rata-rata 3,19 dengan kategori cukup baik, karena fasilitas penerangan di dalam kantor sudah cukup memadai sehingga menciptakan rasa nyaman dalam suasana bekerja. Pernyataan tersebut yaitu : "Penerangan yang ada (sinar matahari dan listrik) di ruang kerja sudah sesuai dengan kebutuhan". Pernyataan tertinggi kedua yaitu pada nomor 10 yang memiliki rata-rata sebesar 3,06 dengan kategori cukup baik, karena hubungan antara karyawan dengan atasan tidak ada batasan jadi dapat saling bekerja sama dalam melakukan pekerjaan. Pernyataan tersebut yaitu : "Saya merasa tidak ada batasan yang menghalangi untuk berkomunikasi dengan atasan". Serta 
pernyataann tertinggi ketiga yaitu pada nomor 11 yang memiliki rata-rata 3,04 karena hubungan antar rekan kerja dan atasan baik. Pernyataan tersebut yaitu : "Saya selalu bersikap ramah terhadap rekan kerja dan atasan".

Adapun pernyataan responden dengan nilai terendah pertama yaitu pada nomor pada nomor 15, yaitu : "Perusahaan menyediakan jenjang karir yang jelas", yang memiliki nilai rata-rata 2,50 dengan kategori cukup baik karena jenjang karir di perusahaan sangat terbatas. Lalu pada pernyataan responden terendah kedua yaitu nomor 7, yaitu : "Keamanan di tempat kerja mampu membuat saya merasa aman" yang memiliki rata-rata 2,67 dengan kategori cukup baik karena karyawan merasa kurang aman dengan adanya beberapa kasus kehilangan barang berharga seperti handphone di dalam ruangan kerja. Kemudian pernyataan responden terendah ketiga yaitu pada nomor 6, yaitu: "Fasilitas kerja yang tersedia saat ini sudah cukup memadai dalam menunjang aktivitas kerja" yang memiliki rata-rata 2,88 dengan kategori cukup baik, karena memang fasilitas yang di sediakan perusahaan sudah cukup memadai sehingga mempengaruhi kenyamanan karyawan dalam melaksanakan pekerjaan.

Variabel Disiplin Kerja (X2) mempunyai 5 dimensi, yaitu Kehadiran, Ketaatan pada aturan kerja, ketaatan pada standar kerja, tingkat kewspadaan tinggi, dan bekerja etis. Berdasarkan hasil penelitian dan pengolahan data Disiplin Kerja (X2) memiliki nilai rata-rata sebesar 3.77 berada pada kategori Cukup Baik. Adapun nilai rata-rata tertinggi pertama yaitu pada pernyataan : "Saya tidak pernah bolos bekerja" dengan nilai rata - rata 3.04 dengan kategori cukup baik, sehingga absensi masing karyawan sudah cukup baik. Lali nilai tertinggi kedua yaitu pada pernyataan : "Saya beretika dan bermoral di lingkungan kerja" dengan nilai ratarata 2,92 dengan kategori cukup baik, sehingga sikap yang diberikan karyawan sudah cukup baik.

Adapun nilai rata-rata terendah yaitu pada pernyataan: "Saya selalu memastikan setiap pekerjaan dilakukan sesuai standar operasional yang berlaku" dengan nilai rata-rata 2,44 dengan kategori kurang baik. Nilai rata - rata terendah berikutnya yaitu pada pernyataan : "Saya mengetahui dan memahami setiap peraturan yang ditetapkan oleh perusahaan" dengan nilai rata - rata 2,46 dengan kategori kurang baik, dimana kedua pernyataan tersebut dikarenakan pemahaman karyawan terhadap peraturan standar operasional di perusahan kurang cukup baik sehingga sangat mempengaruhi kinerja masing-masing karyawan.

Variabel Kinerja (Y) mempunyai 2 dimensi, yaitu Kualitas dan Kuantitas. Berdasarkan hasil penelitian dan penolahan data kinerja karyawan memiliki nilai rata-rata sebesar 2,99 berada pada kategori Cukup Baik. Adapun nilai tertinggi yaitu pada pernyataan : "Saya selalu mendengarkan pelanggan dengan seksama 
untuk menggali \& mengenali kebutuhannya" dengan nilai rata - rata 3.25 dan nilai tertinggi kedua yaitu pada pernyataan : "Saya selalu memastikan bahwa solusi yang saya tawarkan kepada pelanggan sesuai dengan kebutuhannya" dengan nilai rata - rata 3.21 dimana pernyataan tersebut ada pada dimensi kualitas kerja sehingga sudah cukup baik.

Adapun nilai rata - rata terendah yaitu pada pernyataan : Saya selalu bekerja sesuai dengan intruksi yang diberikan oleh pemimpin", yang memiliki nilai ratarata 2,21 dengan kategori kurang baik, karena karyawan belum sesuai perintah yang diberikan pemimpin. Nilai rata - rata terendah berikutnya yaitu pada pernyataan yaitu: "Pencapaian tujuan perusahaan merupakan fokus saya dalam bekerja" dan pernyataan "Saya aktif mengikuti kegiatan diluar perusahaan yang berkaitan dengan upaya peningkatan kemampuan saya pada divisi Call Center Tele Account Management (TAM) Telkom Bandung", yang memiliki nilai ratarata 2,85 dengan kategori Cukup Baik.

Berdasarkan hasil perhitungan pengaruh langsung dan tidak langsung mengenai pengaruh lingkungan kerja (X1) dan disiplin kerja (X2) terhadap kinerja karyawan (Y) bahwa: Total pengaruh lingkungan kerja (X1) terhadap kinerja karyawan (Y) memiliki nilai sebesar 0,369 atau 36,9\%. Total pengaruh lingkungan kerja (X2) terhadap kinerja karyawan (Y) memiliki nilai sebesar 0,362 atau 36,2\%. Hasil total pengaruh lingkungan kerja (X1) dan disiplin kerja (X2) terhadap Kinerja karyawan (Y) sebesar 0,731 atau 73,1\% dan besaran epsilon adalah Py $\in=0,269$ atau $26,9 \%$ yaitu seperti kompensasi, pelatihan kerja karyawan, lingkungan kerja, budaya kerja, kepemimpinan, dan kepuasan kerja.

Dengan hasil perhitungan Koefisien Determinasi $\left(\mathrm{R}^{2}\right)$ yang dinyatakan dalam persentase menggambarkan besarnya kontribusi semua variabel bebas yaitu Lingkungan Kerja (X1) dan Disiplin Kerja (X2) dalam menentukan variabel kinerja sebesar 76,1\% dan besarnya epsilon adalah $\varepsilon=0,239$ atau sebesar $23,9 \%$ yaitu merupakan faktor lain yang mempengaruhi kinerja karyawan, namun tidak diteliti yaitu seperti motivasi, budaya organisasi, kompetensi dan kompensasi. Hasil penelitian ini sejalan dengan penelitian Avey, Reichard, Luthans \& Mhatre (2011) mengemukakan adanya beberapa faktor yang mempengaruhi kinerja yaitu, factor lingkungan dan disiplin individu, factor-faktor individu yang dimakud seperti : (a) usaha yang menunjukkan sejumlah sinergi fisik dan mental yang digunakan dalam menyelenggarakan gerakan tugas. (b) Abilities, yaitu sifat-sifat personal yang diperlukan untuk melaksanakan suatu tugas. Berdasarkan hasil penelitian dan pengolahan data didukung dengan teori tersebut dapat diambil kesimpulan bahwa variabel lingkungan kerja (X1) dan disiplin kerja (X2) secara bersama-sama mempengaruhi kinerja karyawan pada PT Infomedia Nusantara bagian Call Center Tele Account Management (TAM) Telkom Bandung. 
April, 2020

\section{KESIMPULAN}

Berdasarkan uraian dari pembahasan dan hasil penelitian bahwa lingkungan kerja berada pada kategori cukup baik. Disiplin kerja berada pada kategori cukup baik. Kinerja karyawan berada pada kategori cukup baik. lingkungan kerja mempunyai pengaruh terhadap kinerja. Disiplin kerja mempunyai pengaruh terrhadap kinerja. Berdasarkan hasil dari perhitungan menggambarkan besarnya kontribusi semua variable lingkungan kerja (X1) dan disiplin kerja (X2) dalam menentukan variasi Kinerja (Y) adalah sebesar 0,760 atau $76 \%$ dan besaran faktor lain seperti motivasi, kompensasi, pelatihan kerja karyawan, budaya kerja, kepemimpinan, dan kepuasan kerja.

Untuk meningkatkan lingkungan kerja karyawan PT Infomedia Nusantara bagian Call Center Tele Account Management (TAM) Telkom Bandung, sebaiknya perusahaan memberikan kesempatan promosi kenaikan jenjang karir yang lebih banyak agar karyawan memiliki semangat kerja untuk seleksi promo jabatan yang diadakan di lingkungan kerja. Tentunya hal tersebut akan berdampak pada meningkatnya kinerja karyawan. Perusahaan juga harus meningkatkan keamanan di lingkungan ruang kerja agar seluruh karyawan merasa aman karena terjadi beberapa kali kehilangan barang berharga dilingkungan kerja seperti handphone. Selain dari pada itu beberapa fasilitas sarana dan prasarana di lingkungan kerja belum cukup memadai karena banyak yang rusak, sehingga mengakibatkan proses kerja sedikit terganggu. Sedangkan bagi karyawan itu sendiri, diharapkan agar lebih antusias mengikuti setiap perubahan, program atau seleksi promosi jabatan yang sedang dijalankan oleh perusahaan dan juga lebih berhati-hati menyimpan barang berharga maupun menjaga sarana dan prasarana yang sudah tersedia di perusahaan. Untuk meningkatkan disiplin kerja PT Infomedia Nusantara bagian Call Center Tele Account Management (TAM) Telkom Bandung, sebaiknya sejak perekrutan karyawan lebih selektif dan menjelaskan secara terperinci standar operasional yang di tetapkan oleh perusahaan sehingga karyawan memahami posisi sebagai karyawan yang taat akan peraturan di perusahaan, kemudian Sebaiknya perusahaan / atasan memberikan sanksi tegas terhadap karyawan yang tidak disiplin agar tingkat kedisiplinan meningkat, dengan meningkatnya tingkat kedisiplinan kinerja karyawan pun akan meningkat.

Untuk meningkatkan kinerja karyawan PT Infomedia Nusantara bagian Call Center Tele Account Management (TAM) Telkom Bandung, ketegasan atasan (Team Leader) sangatlah diperlukan, mengingat apabila karyawan dibiarkan tanpa pengawasan akan berdampak pada menurunnya tingkat pencapaian target kerja karyawan. Total kinerja karyawan yang tidak pernah mencapai 100\%, hasil kerjanya yang masih mendapat temuan Team Leader sangat perlu diperhatikan. Perusahaan harus mencari cara bagaimana kinerja tersebut bisa terus meningkat seperti dengan karyawan harus mengikuti arahan atau instruksi pembahasan 
April, 2020

materi secara keseluruhan yang di berikan oleh pemimpin pada saat briefing dengan jelas dan mudah dimengerti oleh karyawan sehingga hasil kinerja karyawan dapat mencapai target yang telah ditetapkan. Keinginan karyawan untuk berupaya meingkatkan kemampuannya dengan mengikuti kegiatan di luar perusahaan pun masih minim. Perusahaan juga perlu mengapresiasi karyawan yang sudah bekerja cukup baik menjadi lebih baik lagi sehingga, selain untuk kedepannya karyawan lain yang masih kurang baik kinerjanya dapat menjadikannya contoh untuk mampu meningkatkan kinerjanya sesuai tujuan perusahaan secara optimal.

Untuk kedepannya perusahaan diharapkan dapat meningkatkan profitabilitas, hal ini dikarenakan profitabilitas berpengaruh positif terhadap nilai perusahaan. Dalam peningkatan profitabilitas maka secara idak langsung nilai perusahaan pun akan meningkat. Perusahaan perlu memperhatikan jumlah hutang yang dimiliki perusahaan, ketika jumlah hutang melebihi modal sendiri maka akan menyebabkan leverage mengalami kenaikan. Hal ini dikarenakan Leverage berpengaruh secara negaif, yang artinya ketika terjadi kenaikan leverage maka akan berakibat pada penurunan nilai perusahaan.

\section{REFERENSI}

Avey, J. B., Reichard, R. J., Luthans, F., \& Mhatre, K. H. (2011). Meta-analysis of the impact of positive psychological capital on employee attitudes, behaviors, and performance.Human resource development quarterly, 22(2), 127-152.

Bommer, W. H., Johnson, J. L., Rich, G. A., Podsakoff, P. M., \& MacKenzie, S. B. (1995). On the interchangeability of objective and subjective measures of employee performance: A meta-analysis. Personnel psychology, 48(3), 587-605.

Bugdol, M. (2018). A Different Approach to Work Discipline. Human Resource Management. Palgrave Macmillan: Springer International Publishing.

Chandrasekar, K. (2011). Workplace environment and its impact on organisational performance in public sector organisations. International journal of enterprise computing and business systems, 1(1), 1-19.

Dirks, K. T., \& Ferrin, D. L. (2000, August). The Effects of Trust In Leadership On Employee Performance, Behavior, And Attitudes: A Meta-Analysis. In Academy of management proceedings (Vol. 2000, No. 1, pp. 1-1). Briarcliff Manor, NY 10510: Academy of Management.

Mangkunegara, A, A, A, P. (2011). Manajemen Sumber Daya Manusia Perusahaan Bandung: Rosda. 
April, 2020

Motowidlo, S. J., \& Kell, H. J. (2012). Job performance. Handbook of Psychology, Second Edition, 12.

Pindek, S., \& Spector, P. E. (2016). Organizational constraints: a meta-analysis of a major stressor. Work \& Stress, 30(1), 7-25.

Rivai, V. (2011). Manajemen Sumber daya Manusia Untuk Perusahaan Dari Teori Ke Praktik. Jakarta: RajaGrafindo Persada.

Sutrisno, E. (2010). Manajemen Sumber Daya Manusia. Edisi Pertama. Cetakan Pertama, Jakarta: Penerbit Kencana.

Sedarmayanti. (2013). Manajemen Sumber Daya Manusia. Bandung: Refika Aditama.

Soss, J., Fording, R., \& Schram, S. F. (2011). The organization of discipline: From performance management to perversity and punishment. Journal of Public Administration Research and Theory,21(suppl_2), i203-i232. https://doi.org/10.1093/jopart/muq095

Wood, A. J. (2018). Powerful times: Flexible discipline and schedule gifts at work. Work, Employment and Society, 32(6), 1061-1077. 